Kamila Rezmer-Płotka

Nicolaus Copernicus University

\title{
Language of Contemporary Polish Politics
}

Book Review: Wojciech Krzysztof Szalkiewicz, Marek Sokołowski, Logos, Ethos, Pathos III i IV RP. Dyskurs komunikacyjny polityki, Adam Marszałek Publishing House, Toruń 2019, pp. 369.

The publication of Wojciech Krzysztof Szalkiewicz and Marek Sokołowski is the next publication in the popular series Social Communication - Media Communication - Network Communication. It refers to the politics and language used in public discourse. The authors undertook subject that is extremely interesting, but at the same time causing many difficulties for all researchers who undertake political language analysis. One of the most interesting articles in this area is the article Język dyskursu publicznego w polskim systemie politycznym by Alina Balczyńska-Kosman (2013, pp. 143-154), while Agnieszka Stępińska, Jakub Jakubowski, Dorota Piontek undertook an analysis of research tools in terms of their usefulness for research into populist political communication in article Methodological Challenges for International Empirical Studies on Populist Political Communication (Stępińska, Jakubowski, Piontek, 2017, pp. 226-267). In the geopolitical dimension, Micha1 Lubina considered it in the article From Geopolitical Chance to Security Threat: Polish Public Political Discourse on the One Belt One Road Initiative (Lubina, 2017, pp. 221-238). Institutional aspect was analyzed in the study of Joanna Marszałek-Kawa and Danuta Plecka in the article Social Security as a Factor Contributing to the Evolution of the Political System in Poland after the Parliamentary Elections of 2015 (MarszałekKawa, Plecka, 2017,pp. 79-94.).

The authors of the reviewed publication worked on many difficult threads and demonstrated extraordinary knowledge of the topics dominating in the discourse of the contemporary politics in Poland. In the first chapter, which is a kind of introduction to the deliberations, there are investigations into the language of politics aimed at defining the issue. The second chapter is an attempt to reconstruct the events and statements related to them, 
which led to the appearance of a kind of dissonance and talking about the Third Republic and the Fourth Republic. The authors, apart from statements that make smile, include referrence to the Tinky Winky handbag (p.71), they also referred to high-profile scandals, e.g. the ground scandal (p. 73), as well as popular slogans like „hide grandma's evidence!” (p. 74), „Mordo you mine!” (p. 74) and other less comical but important events that could have contributed to the concept of the Fourth Republic. The next chapter is the authors' efforts to explain the genesis of the so-called Polish-Polish war. In addition to outlining the historical outline, it seeks the ideological foundations of the conflict in Poland and focuses on analyzing the etymological foundations of labels, epithets and invectives often used against political opponents. Chapter IV refers to hate speech, a disturbing phenomenon, especially if one considers the potential and actual threats arising from it. Referring even to the tragic death of Gdańsk' President Paweł Adamowicz, which the authors mentioned in the chapter devoted to the Polish-Polish war (p. 105) and the progressive polarization of the society, by using phrases such as ,the worst sort of Poles" (p. 169). Then, the authors undertook the topic of media information in the times of so-called post-truth, i.e. the greater role of emotions and beliefs in shaping public opinion than referring to facts (p. 177). The next chapter presents the Smolensk disaster and its victims as a political game tool. The penultimate chapter refers to reflections on Polish politics in the international dimension, which is also the subject of internal political struggle, such as the famous „27:1 victory” (p. 284) or „Filipino disease” (p. 288). The last chapter is devoted primarily to recordings that became the beginning of the so-called eavesdropping scandal. In addition, quotes and terms that have been used in politics for years, such as „ośmiorniczki” (p. 311), ,misiewicze” (p. 325) or the popular slogan „How to live, Mr. Prime Minister” (p. 329). They all relate to compromising situation politicians.

However, the publication is not without weaknesses. First of all, the introduction does not indicate that it is a scientific monograph. A humorous tone or offensive wording of, for example, diplomats (wordplay: combining the words of diplomats with a fairy-tale character - Matołek the Billy Goat, who was not very clever) (p. 21) rather suggests satirical content. There was also a strictly methodological chapter, which, if it was singled out and precisely defined the methods and techniques used in the study, hypotheses, research questions, etc., the work would certainly benefit from it. In addition, the publication does not lack colloquialisms, which are not always justified, citing even the sooner indicated formulation or subjective assessments. Also, the language used in the book does not fully meet the formal criteria set for the scientific language. It quite often takes on the features of journalistic style and the language of sources.

Despite some critical remarks, the position is undoubtedly one of the best policy discourses in the field of communication. The authors showed very good knowledge on the topic, presented in an interesting and accessible way, constituting a coherent whole in substantive terms. The issues discussed in the publication are important and constitute an important point for reflection on the condition of Polish politics and the language used by 
politicians. An undoubted advantage is also the password index placed at the end of the book, which allows to quickly find the thread or definition that interests us. This is a great proposition not only for political scientists and other social science researchers, but also for people who are not scientists and are interested in current politics.

\section{References}

Balczyńska-Kosman, A. (2013). Język dyskursu publicznego w polskim systemie politycznym. Środkowoeuropejskie Studia Polityczne, No. 2, pp. 143-154.

Lubina, M. (2017). From Geopolitical Chance to Security Threat: Polish Public Political Discourse on the One Belt One Road Initiative. Polish Political Science Yearbook, vol. 46, No. 1, pp. 221-238. Marszałek-Kawa, J., Plecka, D. (2017). Social Security as a Factor Contributing to the Evolution of the Political System in Poland after the Parliamentary Elections of 2015. Srodkowoeuropejskie Studia Polityczne, No. 4, pp. 79-94.

Stępińska, A., Jakubowski, J., Piontek, D. (2017). Methodological Challenges for International Empirical Studies on Populist Political Communication. Athenaeum, No. 56, pp. 226-267.

\section{Author}

Kamila Rezmer-Płotka, kamila.rezmer@onet.pl - Nicolaus Copernicus University (Poland) 
